\title{
Optimisme pada Wanita Lanjut Usia yang Mengalami Kematian Pasangan Hidup
}

\author{
Fetty Nur Tiyaningsih, Santi Sulandari \\ Fakultas Psikologi, Universitas Muhammadiyah Surakarta, Indonesia \\ e-mail:ss280@ums.ac.id
}

\begin{abstract}
This study aims to describe the problem, the form of optimism, and influential factors of optimism on elder people who experienced loss of the loved ones. This study used quantitativephenomenology with the data collection used semi-structured interviews. The informants were recruited using purposive sampling technique with the total of five elder widows in Sragen. The data was analyzed using thematic analysis. The information record, member-checking, and data delivery were implemented to maintain data validity and objectivity. The results show that the problem after the loss including the feel of loss, decrease of economic condition, loneliness, and health degradation. In overcoming the problems, they were not easily give up and despair, always accept the changes, and have a good hope on their life events. These ability occured because of the willingness to bounce back, attention and support from the closest people. The importance of optimism lead to a motivation from inside the elder widow to rise up and have positive thoughts on life problems they experienced.
\end{abstract}

Keywords: optimism, elderly, spouse died

\begin{abstract}
Abstrak
Penelitian ini bertujuan untuk mendeskripsikan permasalahan, bentuk optimisme, dan faktor pendorong optimisme pada lanjut usia yang mengalami kematian pasangan hidup. Penelitian ini bersifat kualitatif-fenomenologi dengan pengumpulan data menggunakan wawancara semi terstruktur. Informan dipilih menggunakan teknik purposive sampling dengan jumlah lima informan janda lansia di daerah Sragen. Teknik analisis data menggunakan tematic analysis. Pencatatan informasi, member-checking, dan penyampaian data dilakukan untuk menjaga validitas dan objektivitas data. Hasil dari penelitian ini didapatkan bahwa permasalahan setelah ditinggal pasangan yaitu merasa kehilangan, mengalami penurunan perekonomian, kesepian, dan mengalami penurunan kesehatan. Permasalahan tersebut dihadapi dengan tidak mudah menyerah dan putus asa, selalu menerima perubahan yang ada pada dirinya, serta berpengharapan baik atas peristiwa dalam hidupnya. Hal itu mampu dilakukan karena adanya kemauan untuk bangkit, perhatian, dan dukungan dari orang-orang terdekat. Pentingnya optimisme tersebut memunculkan rasa semangat dari dalam diri janda lansia untuk bangkit dan berbaik sangka atas persoalan hidup yang mereka alami.
\end{abstract}

Kata Kunci: optimisme, lanjut usia, kematian pasangan hidup

\section{Pendahuluan}

Bertambahnya usia seseorang akan mengantarkan setiap individu pada proses menua atau periode lanjut usia (lansia) yang berada pada usia kisaran 60 tahun ke atas (Pasmawati, 2017). Berdasarkan data Kementerian Kesehatan RI (2017), Asia dan Indonesia sejak tahun 2015 sudah memasuki era penduduk menua (ageing population) karena jumlah penduduknya yang berusia 60 tahun ke atas (penduduk lansia) melebihi angka 7 persen. Terdapat tiga provinsi di Indonesia yang memiliki persentase lansia terbesar yaitu: Daerah Istimewa Yogyakarta (13.81\%), Jawa Tengah (12.59) dan Jawa Timur (12.25\%).

Angka harapan hidup perempuan lebih tinggi daripada laki-laki, terlihat dari keberadaan penduduk lansia perempuan (9.53\%) yang lebih banyak daripada lansia 
laki-laki (8.54\%) (Kementerian Kesehatan RI, 2017). Sedangkan Badan Pusat Statistik (BPS) Indonesia telah menyebutkan bahwa di tahun 2020, usia harapan hidup meningkat $.18 \%$ dari tahun 2019 menjadi 71.47 tahun (BPS, 2020). Meningkatnya umur harapan hidup (UHH) merupakan salah satu faktor utama terkait kesehatan pada setiap orang, tanpa terkecuali lanjut usia juga mempunyai harapan untuk tetap sehat. Meningkatnya UHH juga akan menimbulkan konsekuensi terhadap tantangan yang akan dihadapi individu di usia lanjut.

Impisari (2017) menyatakan masyarakat Indonesia sejak dahulu senantiasa memberi tempat yang layak bagi para lansia. Lansia selalu ditempatkan pada kedudukan yang istimewa, yaitu sebagai panutan, narasumber atau penasihat ketika berupaya untuk pengambilan suatu keputusan dalam keluarga. Namun hasil penelitian yang telah dilakukan menyebutkan bahwa pada kenyataannya permasalahan yang dihadapi lansia terkadang masih sering terjadi karena kurangnya semangat dan dukungan dari keluarga ataupun orang terdekat. Meskipun demikian, sifat, kemampuan, dan jenis masalah yang dihadapi akan mempengaruhi bagaimana lansia akan mampu menyelesaikan masalahnya dengan atau tanpa bantuan orang lain. Penyelesaian masalah juga akan berhasil jika lansia mampu menunaikan tugas perkembangan pada lanjut usia, yaitu: mampu beradaptasi dengan kekuatan dalam dirinya yang mulai tidak stabil seperti dahulu lagi contohnya pada fisik dan kesehatan, beradaptasi dengan masyarakat sekitar, menyesuaikan diri dengan masa pensiun yang menyebabkan penurunan pendapatan sebelumnya, beradaptasi dengan kepergian pasangan hidup serta membentuk relasi lanjut usia yang sebaya lainnya (Hurlock, 2012).

Selaras dengan Mehue dkk. (2016) yang menyebutkan permasalahan pada lansia diantaranya mengenai perubahan fisik pada penampilan lansia, dianggap sebagai bagian dari penuaan normal, seperti rambut beruban, keriput penuaan pada wajah, hilangnya ketajaman indera, dan menurunnya kekebalan tubuh, namun hal tersebut adalah acaman bagi integritas lansia. Belum lagi mereka harus beradaptasi dan berurusan dengan kerugian yang timbul dalam peran diri, status sosial serta pemisahan dari orang yang dicintai baik perceraian maupun karena kematian. Kondisi di atas menyebabkan lansia lebih rentan mengalami berbagai masalah mental terkait perasaan sedih, tidak berdaya, dan pesimisme yang terkait dengan kesengsaraan diri mereka sendiri atau perasaan marah yang mendalam. Hal tersebut dapat terjadi secara spontan atau sebagai reaksi terhadap perubahan dalam proses kehidupan, misalnya karena mengalami cacat fisik atau mental yang menyebabkan ketergantungan pada orang lain, suasana kesedihan, serta kematian pasangan.

Paparan di atas sejalan dengan penelitian Ekowati (dalam Rahmawati \& Saidiyah, 2016) pada Lansia yang terdiri dari 68 subjek lanjut usia dengan jumlah 36 subjek lanjut usia wanita dan 32 subjek lanjut usia pria, subjek dalam penelitian memiliki penyesuaian diri yang positif terhadap hilangnya pasangan hidup yang menunjukkan hasil uji-t yaitu ada perbedaan signifikan mengenai penyesuaian diri terhadap hilangnya pasangan hidup pada lanjut usia antara pria dan wanita. Dibanding lanjut usia wanita hasil penelitian menyatakan bahwa kemampuan menyesuaikan diri terhadap hilangnya pasangan hidup pada lanjut usia pria terlihat lebih banyak terjadi.

Sejalan dengan paparan di atas, Santrock (2002) berpendapat bahwa tidak seorang pun mampu membayangkan jika akan menjalankan kehidupannya sendiri, terlebih ketika akan ditinggal pergi untuk selamanya ataupun berpisah dengan teman hidupnya dalam jangka waktu lama, ditambah lagi jika sudah bersuami istri 
selama belasan bahkan puluhan tahun lamanya. Karena menurut beberapa survei, kehilangan yang paling sulit dilalui setiap orang adalah ketika harus kehilangan seseorang yang sangat dicintai dan merupakan bagian dari hidupnya seperti pasangan hidup.

Kehilangan seseorang yang sangat penting memang sangatlah menyulitkan bagi seseorang yang telah terbiasa hidup bersama. Hal tersebut sesuai dengan hasil penelitian Rismawan (2015) yang menyatakan bahwa dari keempat responden yang telah diwawancarai semuanya menyatakan merasa sedih dan juga kesepian ketika ditinggal pasangan hidupnya, akan tetapi pada akhirnya responden mampu menerima kenyataan yang ada dengan sikap ridha dan menyerahkan diri kepada sang pencipta. Sedangkan salah satu responden tidak dapat menerima kenyataan tersebut dan merasa putus asa, sehingga membuat responden itu sakit, namun pada akhirnya responden tersebut mulai menyadari dan menerima hal tersebut sebagai cobaan dari Allah Swt.

Terlebih apabila hal tersebut terjadi pada lansia yang mana di usia lanjutnya mulai mengalami penurunan kemampuan dalam beberapa hal, belum lagi mereka harus beradaptasi dan berurusan dengan kerugian yang timbul dalam peran diri, status sosial serta perpisahan dengan orang yang dicintai, baik perceraian maupun kematian yang terjadi secara mendadak. Kondisi tersebut menyebabkan lansia lebih rentan mengalami berbagai masalah mental terkait perasaan sedih, tidak berdaya, dan pesimisme yang terkait dengan kesengsaraan diri mereka sendiri atau perasaan marah yang mendalam. Hal tersebut dapat terjadi secara spontan atau sebagai reaksi terhadap perubahan dalam proses kehidupan, sama halnya pada seseorang yang mengalami cacat fisik atau mental yang menyebabkan ketergantungan pada orang lain sehingga membuatnya mengalami kesedihan dan sensitivitas yang berlebih (Mehue dkk., 2016).
Solusi yang dapat digunakan dari beberapa hal yang akan terjadi pada lansia, umumnya wanita lanjut usia bisa hidup bersama salah satu dari anaknya yang sudah berumah tangga, agar lebih terjamin dan tidak merasa kesepian (Desiningrum, 2014). Selain itu faktor internal dari individu seperti optimisme merupakan suatu alternatif yang dapat membuat lansia lebih dapat menikmati hidup. Optimisme diharapkan mampu membangkitkan semangat pada lansia dalam menjalankan beberapa tugas perkembangannya dan menjadi solusi dari permasalahan yang dialami lansia. Pada umumnya optimis (Safarina, 2016) diartikan sebagai keyakinan bahwa apa yang terjadi atau dialami seseorang saat ini adalah baik, dan masa depan akan memberikan suatu harapan seperti apa yang kita harapkan. Walaupun terkadang mengalami suatu kesulitan, namun harus tetap optimis dan yakin bahwa kesulitan yang saat ini sedang dialami itu sesungguhnya baik untuk perkembangan diri, dan dibalik kesulitan yang sedang dialami pasti ada kesempatan untuk mencapai suatu harapan yang baik.

Anzaldi dan Shifren (2018), Chung dkk. (2016) serta James dkk. (2019) menyebutkan bahwa optimisme merupakan harapan, bahwa hal-hal baik akan terjadi dan berhubungan dengan perasaan dan pikiran yang positif akan masa depan. Abdullah (2018) menambahkan bahwa optimisme merupakan suatu kata yang berasal dari bahasa Latin "optimal", yang berarti 'terbaik". Istilah itu mengacu pada pola pikir dimana seseorang memegang harapan positif secara keseluruhan dalam situasi tertentu dan tentang masa depan. Sejalan dengan pendapat Putri dkk. (2015) bahwa optimisme merupakan kecenderungan individu untuk mengharapkan hasil yang baik, yang membuat individu mengatribusikan masalah dan hambatan yang muncul dalam hidupnya sebagai sesuatu yang bersifat tidak stabil, eksternal, dan penyebabnya spesifik sehingga 
individu harus tetap menjalankan hidupnya sesuai dengan tujuan.

Optimisme dibutuhkan dalam diri lansia agar dapat menghadapi kehidupan yang akan datang dengan keyakinan diri yang penuh dan mampu mengatasi tantangan tanpa rasa cemas dalam diri. Salah satu dimensi optimisme yaitu harapan, harapan untuk masa depan diperoleh dari pandangan individu terhadap penyebab kejadian masa lalu.

Penelitian yang dilakukan Chopik dkk. (2015) juga menunjukkan bahwa optimisme semakin meningkat pada orang dewasa dari usia 50 sampai sekitar 70 tahun, kemudian menurun pada orang dewasa di atas usia 70, menunjukkan bahwa puncak optimisme pada sekitar usia 68 dalam analisis cross-sectional. Selain itu, peningkatan optimisme selama periode 4 tahun dikaitkan dengan peningkatan kesehatan yang telah dilaporkan sendiri dan penyakit kronis lebih sedikit selama rentang waktu yang sama. Meskipun penelitian sebelumnya menyinggung beberapa temuan yang sama, penelitian ini merupakan studi pertama yang meneliti bagaimana perubahan optimisme pada orang dewasa yang lebih tua dan bagaimana perubahan optimisme terkait dengan perubahan dalam kesehatan.

Hal tersebut sesuai dengan hasil wawancara awal yang dilakukan kepada informan W (65 tahun) di Sragen, W tetap memilih tinggal sendiri di rumahnya, terkadang saat akhir pekan cucunya datang untuk menemani. W mengungkapkan bahwa permasalahan yang timbul setelah suaminya meninggal antara lain mulai merasa kehilangan akan kehadiran sang suami yang biasanya setia menemani, baik saat di dalam rumah maupun beberapa acara di luar rumah, dan harus menghadapi permasalahannya sendiri seperti ketika harus meneruskan pekerjaan untuk mencukupi kebutuhannya tanpa mengandalkan hasil pensiunan sang suami. Namun selang berjalannya waktu, W menyatakan bahwa dirinya hanya butuh waktu untuk beradaptasi, karena setiap yang hidup pasti akan mati, jadi $\mathrm{W}$ memilih tetap bersemangat dengan tidak mudah menyerah untuk tetap berusaha melanjutkan hidupnya dengan melakukan aktivitas seperti biasanya tanpa mengeluh, tetap bekerja semampunya dan tetap berkomunikasi dengan anak-anak juga tetangga agar tidak merasa kesepian. Motivasi terpenting menurutnya yaitu melihat anak-anak yang selalu ada untuknya, juga keyakinannya terhadap kebaikan sang kuasa yang akan menolongnya dalam keadaan apapun. Kegigihannya dalam berupaya menghadapi permasalahan dan tantangan hidup yang ada seperti bangkit dari rasa kehilangan dan kesepian, juga selalu berusaha tetap manjalankan aktivitasnya dengan berkeyakinan baik membuatnya mampu bertahan menjalankan kehidupannya hingga sekarang meskipun tanpa suami. Tujuan dari penelitian ini untuk mendeskripsikan permasalahan, bentuk optimisme, dan faktor pendorong optimisme janda lanjut usia yang mengalami kematian pasangan hidup.

\section{Metode Penelitian}

Penelitian ini menggunakan metode kualitatif dengan pendekatan fenomenologi, dimana peneliti akan mencoba memahami makna kejadian atau peristiwa dan kaitannya terhadap orang-orang yang berada dalam situasi tertentu. Fenomenologi diartikan sebagai pendekatan metodologis yang mencoba memberikan pandangan komprehensif tentang pengalaman individu. Pendekatan ini memahami, menggambarkan, dan menafsirkan perilaku manusia dan makna yang dibuat individu dari pengalaman mereka. Penelitian kualitatif ini juga dapat mendorong peneliti menemukan fakta baru yang belum pernah diungkap pada penelitian sebelumnya. Teknik pengambilan sampel yang digunakan dalam penelitian ini adalah purposive sampling dengan kriteria: 1) berusia lebih dari 60 tahun, 2) berstatus janda (pasangan meninggal), 3) tidak menikah lagi, dan 4) tinggal di 
Sragen. Penelitian ini melibatkan lima informan. Peneliti memperhatikan beberapa hal yang menjadi etika dalam penelitian kualitatif sebelum proses pengambilan data. Pertama, adanya informed consent (persetujuan dari informan bahwa ia akan menjadi bagian dari penelitian). Kedua, prinsip kerahasiaan (peneliti menjamin kerahasiaan identitas informan, kecuali apabila informan tidak menuntut kerahasiaan identitas dirinya). Ketiga, adanya prinsip bahwa penelitian yang akan dilakukan tidak membahayakan atau memungkinkan terjadinya bahaya terhadap informan.

Metode pengambilan data yang diguna-kan adalah wawancara semi terstruktur. Peneliti menyiapkan panduan wawancara sebelum penelitian dilaksanakan. Panduan wawancara meliputi pertanyaan penelitian mengenai: "permasalahan apa saja yang dialami janda lansia sebelum dan sesudah ditinggal meninggal pasangan", "bagaima-na optimisme yang muncul dalam menghadapi beberapa permasalahan hidup" dan "faktor apa saja yang mendorong janda lansia tersebut agar dapat bangkit dari peristiwa yang dialaminya". Panduan tersebut dimaksudkan untuk mengantisipasi jawaban atau respon informan agar tidak melenceng terlalu jauh dari fokus penelitian. Setelah proses wawancara selesai kemudian informasi atau data ditranskrip dalam bentuk tulisan oleh peneliti. Setelah itu peneliti kembali melakukan pencatatan informasi dengan mengambil konten dari masing-masing pernyataan yang telah dilontarkan oleh informan. Setelah itu peneliti melakukan member check dari hasil catatan yang didapatkan, peneliti menyampaikan kem-bali kepada informan untuk memastikan jawaban yang telah diutarakan peneliti sesuai dengan keakuratan data informan sehingga tidak terjadi perbedaan persepsi antara peneliti dengan informan.

Data yang didapat dikatakan valid apabila informan dapat menyetujui bahwa serangkaian kalimat yang telah diucapkan kembali oleh peneliti tersebut sesuai dengan penyampaian informan sebelumnya dan sesuai dengan pengalaman informan. Teknik pengolahan data yang digunakan yaitu dengan melakukan teknis tematic analysis. Teknik analisis menggunakan tematic analysis merupakan salah satu cara untuk menganalisa data dengan tujuan untuk mengidentifikasi pola dan menemukan tema melalui data yang telah dikumpulkan.

\section{Hasil Penelitian dan Pembahasan}

\section{Hasil Penelitian}

Subjek dalam penelitian ini terdiri dari lima orang wanita lanjut usia, dengan beragam latar belakang. Profil secara lengkap disajikan pada tabel 1. Usia subjek berkisar antara 60 sampai dengan 67 tahun, pendidikan terakhir mulai SD hingga SLTA, pekerjaan pun beragam meliputi wiraswasta, tukang pijit, pedagang, dan ibu rumah tangga (IRT). Saat ini, keempat subjek tinggal bersama anak mereka, sedangkan satu subjek lainnya tinggal sendiri. Lama waktu menjadi janda pun beragam mulai dari 6 bulan hingga 24 bulan.

Beberapa permasalahan yang muncul setelah suami lansia meninggal dunia yaitu masalah perekonomian. Permasalahan ini sudah ada sejak pasangan masih hidup dan bertambah berat ketika suami meninggal dunia karena suami merupakan tulang punggung keluarga.

Tabel 1

Karakteristik Informan

\begin{tabular}{|c|c|c|c|c|c|}
\hline Informan & I.1 & I. 2 & I. 3 & I. 4 & I.5 \\
\hline $\begin{array}{l}\text { Usia } \\
\text { (tahun) }\end{array}$ & 60 & 66 & 60 & 61 & 67 \\
\hline $\begin{array}{l}\text { Pendidikan } \\
\text { Terakhir }\end{array}$ & SLTA & SD & SMP & SMP & SD \\
\hline Pekerjaan & $\begin{array}{c}\text { Ibu } \\
\text { rumah } \\
\text { tangga }\end{array}$ & $\begin{array}{c}\text { Tukang } \\
\text { pijit }\end{array}$ & $\begin{array}{l}\text { Wira- } \\
\text { swasta }\end{array}$ & $\begin{array}{l}\text { Peda- } \\
\text { gang }\end{array}$ & $\begin{array}{c}\text { Ibu } \\
\text { rumah } \\
\text { tangga }\end{array}$ \\
\hline $\begin{array}{l}\text { Tinggal } \\
\text { dengan }\end{array}$ & Anak & Sendiri & Anak & Anak & Anak \\
\hline $\begin{array}{l}\text { Lama } \\
\text { menjanda }\end{array}$ & 6 bulan & $\begin{array}{c}1.5 \\
\text { tahun }\end{array}$ & $\begin{array}{c}2 \\
\text { tahun }\end{array}$ & $\begin{array}{c}1 \\
\text { bulan }\end{array}$ & $\begin{array}{c}1.5 \\
\text { tahun }\end{array}$ \\
\hline
\end{tabular}


Oleh karena itu informan 2, 4 dan 5 harus berusaha mencukupi kebutuhannya seperti untuk membayar listrik dan kebutuhan pokok. Begitu juga yang dialami informan 3 karena setelah kepergian suami barulah informan merasa perekonomiannya berkurang sehingga membuatnya harus berusaha untuk mencukupi kebutuhan hidupnya. Seperti yang dinyatakan oleh informan 5, "Dari dulu susah mbak saya hidupnya ya, cuma ngandelin mbah kakung, jadi ya ekonominya kurang saya juga nggak kerja Cuma tani kan kerja susah mbak jadi ya itu seadanya sebagian buat beli keperluan saloke yo dingge mbayar pajek listrik kui (sebagian untuk membayar pajak listrik)."

Berbeda dengan informan 1 yang tidak mengalami permasalahan perekono-mian sepeninggal suami, karena selain dari sisa uang pensiun yang ditinggalkan suami, anak-anaknya selalu mencukupi kebutuhannya.

Permasalahan lainnya yang muncul setelah suami meninggal adalah rasa kehilangan yang dialami oleh seluruh informan. Sebelumnya, dalam keseharian informan selalu ditemani pasangan ketika di rumah dan beraktivitas. Seperti yang disampaikan informan 4, "Ya kalau bapak setelah nggak ada itu... ya gimana ya...ya kehilangan.. namanya kepala keluarganya yang mengatur yang jadi panutan nggak ada... tapi ya intinya disini itu...kita ya agak-agak nggak penuh gitu aja, tapi ya karena itu kehendak-Nya ya sudah diikhlaskan saja gitu aja...kalau tidak diikhlaskan kalau saya tangisin pasti ya nggak pulang lagi, nggak kembali lagi, udah lah karena itu sudah takdir...ya begitu aja, kasihan kalau ditangisin terus meskipun hati ini ya pastinya sedih kehilangan bapak, kan berasa di rumah sepi, biasanya sliwar sliwer gitu ya doakan yang disana juga biar tenang."

Kesepian juga dialami oleh informan karena tidak adanya sosok suami di sampingnya seperti yang dirasakan informan 2, 3, dan 4. Mereka menyampai- kan bahwa dulu mereka memiliki teman untuk berdiskusi dan berkeluh kesah. Namun sekarang ini mulai terasa jenuh. Hal ini berbeda dengan yang dirasakan informan 1 dan 5, menurutnya kehadiran sang anak dan cucu yang tinggal bersamanya mampu membuat mereka tidak merasakan kesepian. Informan 3 menyatakan: "Oh itu, ya kesepian...itu setiap harinya dulu kan bapak ada, kalau nggak ada ya saya sendiri, ada yang hilang...begitu anak saya kerja saya di rumah sendiri, kalau cucu kalau kemari kan ya cuma sebentar gitu jadi kan saya sendiri lagi gitu, jadi kadang suka sepi gitu kalau...di rumah ya saya melakukan kegiatan lain ikut pengajian, senam gitu, kadang-kadang kalo kangen bapak ya didoain langsung sholat". Informan 4 juga menyatakan hal yang sama, "Sedih kehilangan bapak....kan berasa di rumah sepi....biasanya sliwar sliwer (ada di sini) gitu, ya doakan yang disana juga biar tenang".

\begin{tabular}{|c|}
\hline Permasalahan \\
\hline $\begin{array}{l}\text { Perekonomian } \\
\text { 1) Kesulitan untuk membayar listrik }(2,4,5) \\
\text { 2) Kesulitan memenuhi kebutuhan hidup }(2,3,4,5) \\
\text { 3) Kesulitan dalam membayar hutang }(5)\end{array}$ \\
\hline $\begin{array}{l}\text { Kehilangan } \\
\text { Rasa kehilngan karena ditinggalkan oleh sosok } \\
\text { suami yang biasanya selalu menemani setiap hari } \\
\text { dirumah telah tiada }(1,2,3,4,5)\end{array}$ \\
\hline $\begin{array}{l}\text { Kesepian } \\
\text { Tidak ada teman untuk berbagi keluh kesah } \\
\text { ketika dirumah sendiriansehingga membuatnya } \\
\text { merasa jenuh }(2,3,4)\end{array}$ \\
\hline $\begin{array}{l}\text { Kesehatan menurun } \\
\text { Penurunan kemampuan daya tahan tubuh (fisik): } \\
\text { 1) Merasa pegal apabila jongkok terlalu lama (1) } \\
\text { 2) Kesulitan untuk berdiri terlalu lama sehingga } \\
\text { harus memakai tongkat }(2,5) \\
\text { Penurunan kemampuan dalam penglihatan : } \\
\text { 1) Kurang dapat membaca dengan jelas dan } \\
\text { memerlukan bantuan kaca mata }(1,5)\end{array}$ \\
\hline
\end{tabular}

Gambar 1. Permasalahan pada lansia 
Permasalahan terkait kesehatan yang mulai menurun karena faktor pertambahan umur juga dialami oleh informan 1, 2 dan 5. Masalah kesehatan ini, berupa: mulai merasa pegal apabila harus jongkok terlalu lama (informan 1); kesulitan untuk berdiri terlalu lama sehingga membutuhkan bantuan tongkat (informan 2 dan 5); dan juga ketidakmampuan membaca dengan jelas dan memerlukan alat bantu kaca mata (informan 1 dan 5).

Terkait hal itu, informan 5 menyatakan, "Mpun dangu mbak...yo kurang luwih setahun bar ninggal kakung kae, kakinya juga lemes sok-sok koyo gringgingen (sudah lama mbak sekitar satu tahun setelah kakek meninngal, kaki terasa lemas dan kesemutan) nggak bisa jalan lancar...terus terapi di Rizky bisa tapi nanti jatuh itu kalau lama-lama jadi kemana mana ya sangu tongkat."

Berdasarkan paparan di atas maka dapat disimpulkan bahwa permasalahanpermasalahan yang muncul pada lansia ketika ditinggal pasangan, meliputi: perekonomian, kehilangan, kesepian, dan kesehatan menurun. Hal tersebut disarikan pada gambar 1 .

\section{Bentuk-bentuk Optimisme}

Keseluruhan informan dalam hal ini mampu menganggap setiap permasalahan hidup yang terjadi padanya hanya sementara, dan dapat dihadapi jika tidak terlalu berlarut-larut dalam kesedihan, selalu berusaha bangkit saat ditimpa kesedihan karena kehilangan suami yang dicintainya, dan bersemangat melanjutkan kehidupannya seperti dengan melakukan kegiatan yang positif. Begitu juga saat mengalami kesulitan ekonomi informan 2, 3, 4 dan 5 tidak mudah putus asa dan kembali berjuang untuk mencukupi kebutuhan dan membayar utang dengan berdagang dan memanfaatkan hasil kebun untuk dijual.

"...Usahanya itu jangan putus asa, harus doa yang banyak pokoknya supaya dimudahkan terus, yang penting yakin aja kita bisa melewati persoalan hidup...." [I.2]

“...Ya kalau saya masalah itu insha allah kita ya bisa melalui,masalah kan cuma sementara nanti juga selesai sendiri jika kita tidak mudah menyerah dan melalui dengan ikhlas..." [I.4]

“...Bersyukur tidak mengeluh, tidak bersedih hati menyalahkan diri sendiri karena semuanya juga mengalami ujian hanya saja kan...carane niku kan benten (caranya berbeda) ....jadi ya tidak berlarut-larut menjadikan beban..." [I.1]

Keseluruhan informan dalam hal ini mengalami kesamaan bahwa dengan keadaan fisik yang semakin renta membuat orang-orang memperlakukan mereka tidak seperti ketika muda dulu. Contohnya saat kegiatan kerja bakti semua informan tidak diperkenankan ikut dalam kegiatan kerja bakti, bahkan ada tetangga yang merasa kasihan dan melarangnya, namun mereka tetap mengikuti beberapa acara di kampung dengan penuh semangat, sehingga meskipun banyak yang mengatakan sudah tua bahkan melarangnya, tidak pernah dimasukkan ke dalam hati karena seluruh informan menyadari bahwa keadaannya yang memang sudah tua, namun mereka tetap mengikuti kegiatan tersebut sesuai dengan kemampuannya. Lalu dengan status barunya sebagai janda, semua informan menerimanya dengan ikhlas.

“...Namanya orang udah tua keriput semua gini badannya kurus ya pasti dikasihani, dianggapnya nanti capek tapi saya nggak papa namanya sudah tua ya kaya gini keadaannya tapi tetep tak jawab aku dah tua masih bisa nyapu...hm...gitu sambil bawa sapu hehe..." [I.2]

“...Anu janda niku ya mbak, insha allah saya lillah, ikhlas mbak karena sudah takdirnya Allah jadi saya legowo (ikhlas)..." [I.1]

Harapan dan tujuan hidup yang baik juga tetap optimis ketika dilanda kebosanan, akan mendorong setiap orang 
yakin dapat melewati hari-harinya dengan berbaik sangka atas kejadian yang akan terjadi padanya. Seperti halnya saat kelima informan ditimpa permasalahan hidup seperti kehilangan suami, menghadapi perekonomian yang serba kekurangan, merasa kesepian dan mengalami penurunan kesehatan, tetapi tetap memiliki harapan dan tujuan hidup yang baik seperti hasil wawancara pada seluruh informan yang mengatakan hal sama dengan informan 2 .

“...Kecukupan itu kalau ada apa-apa tidak kesusahan, tujuannya ya kita kan masih hidup ya...jadi kita usaha yang semangat, jadi anak-anak cucu biar lihat aku sehat senang begitu kehidupannya." [I.2]

Namun tidak jarang aktivitas yang ada, terkadang membuat setiap orang mengalami kejenuhan dalam melewatinya karena beberapa sebab, tetapi kelima informan tetap dapat mengatasinya dengan melakukan hal-hal yang bisa membuat mereka bersemangat kembali, seperti berkebun, menonton televisi atau pergi ke tempat tetangga. Hasil wawancara tersebut dirasakan seluruh informan yang mengatakan hal sama dengan hasil wawancara pada informan 3.

“...Kalau bosen ya cuma ngaji ya nonton tv itu kan hiburan mbak ya teman saya biar ketawa gitu aja biar nggak bosen lagi gitu." [I.3]

Bentuk-bentuk optimisme yang telah dijelaskan di atas, terangkum pada gambar 2.

\section{Faktor Pendorong Optimisme}

Optimisme yang dimiliki oleh janda lanjut usia bertujuan untuk membuat mereka bangkit dari beberapa permasalahan yang dihadapi. Optimisme pada janda lansia muncul karena adanya faktor kemauan dari dalam diri sendiri untuk bersemangat, memiliki religiusitas yang baik dan dukungan dari lingkungan sekitar terutama keluarga dan tetangga yang merupakan orang-orang terdekatnya, juga selalu memberikan dukungan kepada lansia tersebut, sebagaimana disajikan pada gambar 3.

Kemauan dan semangat dari dalam diri sendiri merupakan suatu hal yang terpenting untuk mendorong seseorang mau melakukan suatu hal yang dikatakan berat maupun suatu hal baru yang harus dilaksanakan. Seperti halnya yang dilakukan janda lansia setelah kepergian suami. Kelima informan berusaha untuk menyemangati diri sendiri supaya bangkit dari keterpurukan.

"Nggih...itu makanya, saya selalu masak pagi setelah subuh... itu selalu masak terus sambil mendengarkan tausiah-tausiah itu biar semangat setiap hari mbak." [I.1]

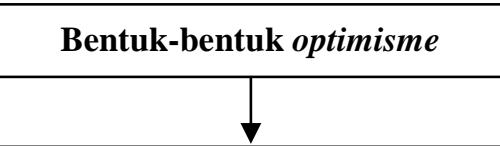

Tidak mudah menyerah dan putus asa

1) Tidak berlarut-larut dalam kesedihan dengan mengikuti pengajian dilingkungan rumah agar hati lebih ikhlas melepas sang suami $(1,2,3,4,5)$

2) Meskipun ditinggal oleh suami namun tetap berusaha mengikuti kegiatan kerja bakti untuk mengisi waktu luang dan berinteraksi dengan tetangga $(1,2,3,4,5)$

3) Tidak menjadikan masalah menjadi beban dengan tetap berusaha mencukupi kebutuhan dengan membuka warung, berkebun, dan menjadi tukang pijat $(1,2,3,4,5)$

Menerima perubahan yang ada pada dirinya

1) Menerima perubahan usia yang sudah tua $(1,2,3,4,5)$

2) Menerima perubahan status nya yang sudah menjanda $(1,2,3,4,5)$

\section{Berpengharapan baik}

1) Selalu semangat ketika dilanda rasa bosan dengan melakukan kegiatan seperti berkebun, melihat tv, menjahit, bersih-bersih halaman, mengikuti pengajian, mengikuti senam, dan renang supaya tetap sehat dan dapat menghibur hati $(1,2,3,4,5)$

2) Mampu optimis dengan selalu beribadah kepada Allah agar diberikan kemudahan dalam meneruskan hidupnya kedepan $(1,2,3,4,5)$

Gambar 2. Bentuk-bentuk optimisme 


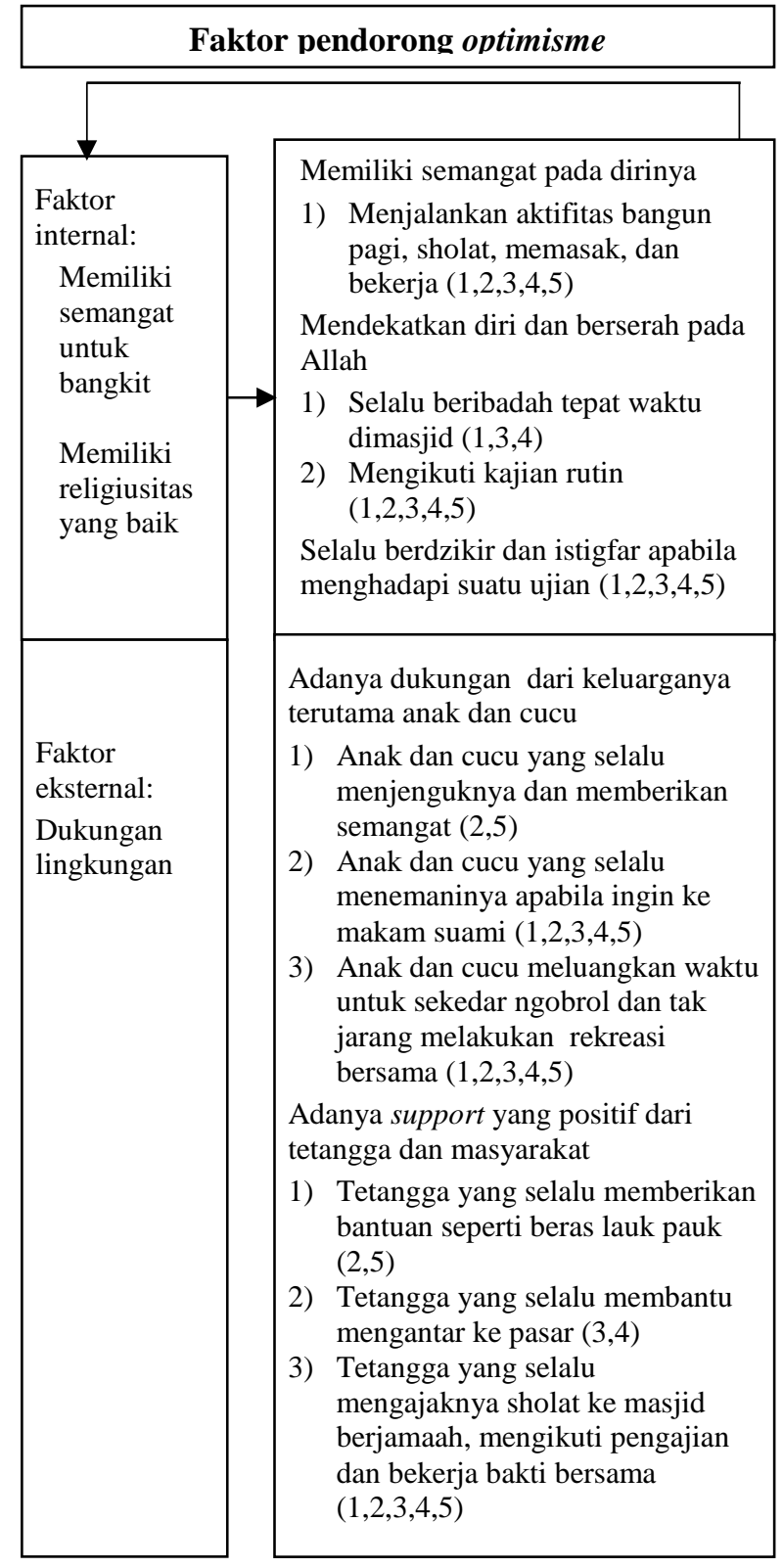

Gambar 3. Faktor pendorong optimisme

"Gimana ya....kalau saya keinget bapak keinget butuh itu, jadi motivasi saya itu ya, saya setiap harinya semangat gitu mbak penggennya ya... mencari kesibukan pokoknya ya... entah cabutan apa motongin rumput, apa cabutin rumput di kebun kebung itu" [I.2]

Hasil wawancara yang dilakukan kepada seluruh informan, menunjukkan bahwa dalam berbagai kejadian, persoalan dan permasalahan hidupnya mereka selalu pasrah dan berserah kembali kepada Allah dengan diiringi usaha yang tiada henti agar mendapatkan ridha dan pertolongan Allah dalam segala hal.

"Usaha saya ya mbak...ya sholat tahajjud.... yo anu baca quran...yo dzikir disela-sela...habis sholat selalu baca quran, dzikir...yo siang, pagi, siang, sore, malem, sama setelah subuh itu selalu masak, terus sambil mendengarkan tausiah di tv, supaya atine ki kuat (supaya hatinya bisa kuat) gitu lho mbak, jadi bisa menerima dan memasrahkan semuanya sama Allah..." [I.1]

Penelitian ini juga menekankan pentingnya dukungan yang baik dan rasa perhatian penuh dari anak-anak, yang membuatnya merasa bersemangat dan tidak mengalami kesepian. Kehadiran anak dan cucu yang selalu mewarnai hari-hari dengan beberapa kegiatan positif bersama. Salah satu diantaranya menyampaikan:

"Oh iya mbak, yang membuat saya terus bangkit nggak murung lagi, ya karena melihat anak-anak, melihat cucu-cucu seneng, jadi kan ada semangatnya mbak, badan rasanya sumringah gitu lho adane itu lupa apa apa yang membuat berat pikiran jadi plong gitu mbak....atine ayem (hati tenang) seneng gitu jadi saya ya nggak mau sedih terus." [I.3]

Perlakuan yang baik dari tetangga sekitar terhadap lansia juga dapat meningkatkan kemauan untuk dapat bertahan dan bangkit dari segala permasalahan hidupnya, seperti yang dirasakan oleh seluruh informan karena adanya dukungan dari lingkungan yang baik dan selalu memberikan bantuan ketika membutuhkan, membuat mereka lebih bersemangat dan mampu untuk optimis melanjutkan hidupnya.

"Melihat anak cucu bisa bekerja semua mudah-mudahan sukses, tonggone kaleh kulo yo apik mbak sok ngekeki beras duwit mboten geting kaleh kulo (semua tetangga saya baik, memberi beras, mereka tidak benci sama saya) kulo pinginne (saya 
inginnya)...ya saya bisa sehat selamanya, yang penting usaha kan mbak.....ngibadah (ibadah) juga meskipun umur sudah enam tujuh ya.. saya yang penting sholat jadi saya tenang mbak nglakoni urip ki aku ayem ngono tho (menjalani hidup dengan tenang).”[I.5]

\section{Pembahasan}

Hasil penelitian ini, terkait permasalahan yang muncul pada janda lansia setelah suaminya meninggal, sejalan dengan Santrock (2002) bahwa kehilangan yang paling mendalam adalah ketika ditinggal meninggal oleh pasangan hidup, tidak seorang pun mampu membayangkan jika akan menjalankan kehidupannya sendiri, terlebih ketika ditinggal pergi untuk selamanya ataupun berpisah dengan teman hidupnya dalam jangka waktu lama, ditambah lagi jika sudah bersuami istri selama belasan bahkan puluhan tahun lamanya. Hal tersebut yang kemudian membuat lansia harus survive dan tidak terpuruk akan keadaan, sehingga mampu bangkit dan melanjutkan hidupnya meskipun tanpa pasangan hidup.

Selaras dengan yang dipaparkan oleh Hurlock (2012); Kelen dkk. (2016); Hanum dkk. (2018), bahwa beberapa masalah yang menyertai lansia yaitu lanjut usia akan mengalami ketergantungan terhadap orang lain yang disebabkan ketidakberdayaan fisik dan menghadapi perubahan total dalam pola hidup karena ketidakpastian perekonomian. Dalam penelitian tersebut juga disebutkan, bahwa rasa sedih merupakan suatu permasalahan psikis pada lansia, yang merupakan faktor penting yang bisa memengaruhi kehidupan seorang lansia diantaranya kesepian. Seorang lansia yang mengalami proses menua dengan terus-menerus ditandai adanya permasalahan pada penurunan daya tahan fisik sehingga rentan terhadap penyakit. Hal tersebut yang menyebabkan beberapa lansia tidak dapat menjalankan aktivitas seperti biasa dan hanya berdiam diri di rumah, yang pada akhirnya lansia tersebut mulai merasa kesepian. Oleh karenanya beberapa lansia mulai berusaha dan berbaik sangka atas kehidupannya ke depan dengan melakukan hal-hal yang baik pula sesuai dengan kemampuannya.

\section{Bentuk-bentuk Optimisme}

Hasil penelitian ini menunjukkan, bahwa lansia yang ditinggal pasangan hidup pasti akan merasakan beberapa kondisi yang baru dan tidak pernah dirasakan sebelumnya, tetapi lansia yang memiliki semangat dan keinginan untuk bangkit dari beberapa permasalahan yang dihadapi pasti akan membuatnya tetap optimis dan mampu melanjutkan kehidupannya ke depan dengan melakukan beberapa kegiatan dan hal-hal yang baik.

Seluruh informan penelitian memiliki kesamaan yaitu mempunyai harapan dan tujuan hidup yang membuatnya bangkit dan bersemangat. Mereka ingin diberikan kesehatan agar selalu bisa berkumpul dan bahagia dengan anak dan cucu, berguna untuk orang banyak, membantu yang kesusahan, tidak merepotkan keluarga, dan ingin berbuat baik untuk bekalnya nanti. Selain itu seluruh informan mampu melalui hari-harinya dengan optimis dan semangat ketika mengalami rasa sepi saat di rumah sendiri, dengan melakukan beberapa kegiatan seperti berenang, berkebun, menerima jasa pijat, beres-beres, melihat acara televisi, dan ada pula yang berjalanjalan ke tempat tetangga atau saudara sehingga membuatnya bersemangat kembali. Hal tersebut juga ditemukan oleh Suwarsi dan Handayani (2017) terkait dengan ciri-ciri individu yang optimis.

Berbeda dengan pendapat Desiningrum (2014) bahwa solusi yang tepat dari beberapa hal yang akan terjadi pada wanita lansia, yaitu hidup bersama salah satu dari anaknya yang sudah berumah tangga agar lebih terjamin dan tidak merasa kesepian. Namun, penelitian ini menunjukkan bahwa lansia yang tinggal di rumah sendiri masih tetap bisa optimis dan semangat dengan 
memiliki harapan baik atas hidupnya ke depan.

\section{Faktor Pendorong Optimisme}

Hasil penelitian ini selaras dengan penelitian Sari (2014) yang menyatakan, selain kemauan dari dalam diri responden untuk bangkit dan meyakini akan hal-hal baik setelah peristiwa yang terjadi padanya, bentuk dukungan sosial yang diberikan berupa perhatian dan mendengarkan keluhan-keluhan responden juga menjadi faktor yang akan meningkatkan rasa optimis responden.

Seligman (2006) menambahkan bahwa religiusitas juga dapat berpengaruh bagi individu dalam pengembangan sikap optimisme. Dalam hal ini, agama dapat menimbulkan seseorang memiliki harapan serta memungkinkan orang itu mampu melewati cobaan hidup di dunia dengan lebih baik. Beberapa studi terdahulu, Koenig dkk. (2015); dos Santos Mendes Mónico \& Alferes (2019); SchuurmansStekhoven (2018) juga menunjukkan adanya peran, baik secara langsung atau tidak langsung, religiusitas/ spiritualitas terhadap optimisme. Hermawati dan Hidayat (2019) juga menambahkan bahwa religiusitas membuat lansia yang kehilangan pasangan, tidak mengalami loneliness.

Penelitian ini tidak mengungkap pengaruh karakteristik atau latar belakang informan terhadap tingkat optimisme lanjut usia. Penelitian lebih lanjut terkait ini perlu dilakukan untuk dapat memahami faktor yang memengaruhi optimisme pada lanjut usia secara lebih terperinci.

\section{Simpulan}

Simpulan yang diperoleh dari penelitian ini bahwa permasalahan yang muncul pada lansia setelah ditinggal suami meliputi rasa kehilangan, perekonomian yang serba kekurangan, kesepian dan kesehatan yang mulai menurun. Beberapa bentuk optimisme yang muncul pada seluruh informan diantaranya: tidak mudah menyerah dan putus asa, mencoba bangkit dan berusaha menyelesaikan permasalahan hidupnya, menerima perubahan yang ada, menerima status baru sebagai janda, serta selalu berpengharapan baik atas segala hal yang menimpa mereka.

Hal tersebut mampu dilakukan karena adanya faktor yang berpengaruh dalam optimisme itu sendiri yaitu adanya religiusitas yang baik, dukungan dari lingkungan, seperti dukungan dari keluarga yaitu anak dan cucu, serta dukungan dari tetangga yang selalu memberikan perlakuan baik kepada para lansia.

\section{Daftar Pustaka}

Abdullah, M. Q. (2018). Optimism/ pessimism and its relationship with locus of control among children and adolescents. Mathews Journal of Psychiatry \& Mental Health, 3(1). 1-9.

Anzaldi, K., \& Shifren, K. (2018). Optimism, pessimism, coping, and depression: A study on individuals with parkinson's disease. The International Journal of Aging and Human Development, 88(3), 231-249. https://doi.org/https://doi.org/10.1177/ 0091415018763401

Badan Pusat Statistik. (2021, April 30). Indeks pembangunan manusia 2020. Badan Pusat Statistik. https://www.bps.go.id/publication

Chopik, W. J., Kim, E. S., \& Smith, J. (2015). Changes in optimism are associated with changes in health over time among older adults. Social Psychological and Personality Science, 6(7), 814-822. https://doi.org/10.1177/194855061559 0199

Chung, M. L., Bakas, T., Plue, L. D., \& Williams, L. S. (2016). Effects of selfesteem, optimism, and perceived control on depressive symptoms in stroke survivor-spouse dyads. Journal of Cardiovascular Nursing, 31(2), 8- 
16.

https://doi.org/10.1097/JCN.00000000 00000232

Desiningrum, D. R. (2014). Kesejahteraan psikologis lansia janda/duda ditinjau dari persepsi terhadap dukungan sosial dan gender. Jurnal Psikologi Undip, $13(2)$, 102-106. https://doi.org/10.14710/jpu.13.2.102201

dos Santos Mendes Mónico, L., \& Alferes V. A. R. (2019). The effect of religious identity on optimism across the lifespan. Dalam García-Alonso J. \& Fonseca C. (eds.), Gerontechnology. IWoG 2018. Communications in Computer and Information Science, vol 1016. Springer, Cham. https://doi.org/10.1007/978-3-03016028-9 32

Hanum, P., Lubis, R., \& Rasmaliah. (2018). Hubungan karakteristik dan dukungan keluarga lansia dengan kejadian stroke pada lansia hipertensi di rumah sakit umum pusat Haji Adam Malik Medan. Jumantik, 3(1), 72-88. http://dx.doi.org/10.30829/jumantik.v3 i1.1377

Hermawati, N. \& Hidayat, I. N. (2019). Loneliness pada individu lanjut usia berdasarkan peran religiusitas. Psikis: Jurnal Psikologi Islami, 5(2), 155166.

https://doi.org/10.19109/psikis.v5i2.26 39

Hurlock, E. (2012). Psikologi perkembangan, suatu pendekatan sepanjang rentang kehidupan (terjemahan). Erlangga.

Impisari, I. N. (2017). Makna kebahagiaan pada lansia muslim yang tinggal di Panti Tresna Werdha Teratai Palembang. Jurnal Intelektualita: Keislaman, Sosial dan Sains, 6(2), 211-228.

https://doi.org/https://doi.org/10.19109 /intelektualita.v6i2.1607

Kelen, A. P., Hallis, F., \& Putri, R. M.
(2016). Tugas keluarga dalam pemeliharaan kesehatan dengan mekanisme koping lansia. Jurnal Care, 4(1), 58-65. https://doi.org/10.33366/cr.v4i1.474

Kementerian Kesehatan RI (2017). Analisis lansia di Indonesia. Kementerian Kesehatan RI. https://pusdatin.kemkes.go.id/downloa d.php?file=download/pusdatin/lainlain/Analisis\%20Lansia\%20Indonesia \%202017.pdf

Kim, E. S., Kubzansky, L. D., Zevon, E. S., Trudel-fitzgerald, C., \& Grodstein, F. (2019). Optimism and healthy aging in women. American Journal of Preventive Medicine, 56(1), 116-124. https://doi.org/10.1016/j.amepre.2018. 07.037

Koenig, H. G., Pearce, M. J., Nelson, B., Shaw, S. F., Robins, C. J., Daher, N. S., Cohen, H. J., Berk, L. S., Bellinger, D. L., Pargament, K. I., Rosmarin, D. H., Vasegh, S., Kristeller, J., Juthani, N., Nies, D., \& King, M. B. (2015). Religious vs. conventional cognitive behavioral therapy for major depression in persons with chronic medical illness: A pilot randomized trial. Journal of Nervous and Mental Disease, 203(4), 243-251.

https://doi.org/10.1097/NMD.000000 0000000273

Mehue, D., Rantetampang, A. L., \& Sandjaja, B. (2016). Factors affecting depression to old age at rehabiliy old age and home family registered health primary Sentani Jayapura Regency Papua province. International Journal of Sciences: Basic and Applied Research (IJSBAR), 30(5), 263-279.

Pasmawati, H. (2017). Pendekatan konseling untuk lansia. Jurnal Syi'ar, 17(1), 49-60. http://dx.doi.org/10.29300/syr.v17i1.9 05

Putri, V. P., Priyatama, A. N., \& Karyanta, N. A. (2015). Hubungan antara efikasi 
diri dan optimisme dengan keterikatan pada karyawan PT . Bank Tabungan Negara (Persero) Cabang Solo. Jurnal UNS, 7(1), 67-81. https://doi.org/10.13057/wacana.v7i1. 77

Rahmawati, F., \& Saidiyah, S. (2016). Makna sukses di masa lanjut. Psympathic: Jurnal Ilmiah Psikologi, 3(1), 51-68. https://doi.org/https://doi.org/10.15575 /psy.v3i1.783

Rismawan, W. (2015). Pemenuhan kebutuhan seksualitas lansia di PSTW Panti Wredha Welas Asih kabupaten Tasikmalaya. Kesehatan Bakti Tunas Husada, 13(1), 156-164. http://dx.doi.org/10.36465/jkbth.v13i1 .28

Safarina, N. (2016). Hubungan harga diri dan optimisme dengan kesejahteraan subjektif pada ahasiswa Magister Psikologi Universitas Medan Area. Analitika, 8(2), 99-107. https://doi.org/10.31289/analitika.v8i2 .868

Santrock, J. W. (2002). Life span development (Ed. ketiga). Erlangga.

Sari, K. (2014). Faktor-faktor yang berhubungan dengan optimisme kesembuhan pada penderita kanker payudara. Jurnal Kedokteran, 1(2), 125-127.

Schuurmans-Stekhoven, J. B. (2018). Conviction, character and coping: religiosity and personality are both uniquely associated with optimism and positive reappraising. Mental Health, Religion and Culture, 21(8), 763-779. https://doi.org/10.1080/13674676.201 8.1542422

Seligman, M. . (2006). Learned optimism: How to change your mind and your life (3rd ed.). Kindle Edition.

Suwarsi, S., \& Handayani, A. (2017). Hubungan antara Optimisme dan problem focused coping pada mahasiswa yang sedang menyusun skripsi. Proyeksi, 12(1), 35-45. http://dx.doi.org/10.30659/jp.12.1.35-

44 
Psympathic, Jurnal Ilmiah Psikologi Juni 2021, Vol.8, No.1, Hal. : 117-130 